\title{
Effektivitas Penggunaan Media $M Y O B$ Pembelajaran Terhadap Hasil Belajar Siswa Pada Mata Pelajaran Akuntansi Kelas XI di SMKN 1 Sakra Kabupaten Lombok Timur Tahun Ajaran 2019/2020
}

\author{
Hadi Gunawan Sakti ${ }^{1}$, Zul anwar ${ }^{2}$ \\ 1,2 Dosen Program Studi Teknologi Pendidikan FIPP-UNDIKMA Mataram \\ e-mail :gunawansakti33@gmail.com
}

\begin{abstract}
Abstrak, Penggunaan media pembelajaran dalam proses belajar mengajar khususnya pada mata pelajaran Akuntansi masih kurang, sampai saat ini masih mengggunakan metode konvensional. Sehingga metode tersebut kurang dapat mening katkan hasil belajar siswa .maka rumusan masalahnya adalah apakah ada efektivitas penggunaan media $M Y O B$ pembelajaran terhadap hasil blajar siswa pada mata pelajaran Akuntansi kelas XI di SMKN 1 Sakra Kabupaten Lombok Timur Tahun Ajaran 2019/2020?. Tujuan penelitian ini adalah untuk mengetahui ada atau tidak Efektivitas Penggunaan Media $M Y O B$ Pembelajaran Terhadap Hasil Belajar Siswa Pada Mata Pelajaran Akuntansi Kelas XI di SMKN 1 Sakra Tahun Ajaran 2019/2020. Metode yang digunakan dalam penelitian ini adalah metode kuantitatif deskriptif dengan pendekatan eksperimen, desain penelitian yang digunakan adalah pola one- group pretet-postest design. populasi yaitu siswa kelas XI, berjumlah 25 orang.Teknik pengumpulan data dalam penelitian ini menggunakan metode tes sebagai motode pokok dan metode dokumentasi sebagai metode pelengkap.Teknik analisis data menggunakan rumus T-test.Hasil analisis menunjukan bahwa t-hitung yang lebih besar dari t-tabel $(12,796>2,064)$ dengan tarif signifikan $5 \%$, berarti Ho ditolak dan Ha diterima yang berbunyi Ada efektivitas Penggunaan Pada Media MYOB Pembelajaran Terhadap Hasil Belajar Siswa Pada Mata Pelajaran Akuntansi Kelas XI Di SMKN 1 Sakra kabupaten Lombok Timur Tahun Ajaran 2018/2019.. Berarti hasil penelitian ini adalah signifikan.
\end{abstract}

Kata Kunci: MYOB Pembelajaran, Hasil Belajar

\section{PENDAHULUAN}

Untuk meningkatkan kualitas prestasi belajar siswa menuju peningkatan mutu pendidikan diperlukan strategi dan program yang lebih efektif dan efisien. Termasuk di dalamnya sarana dan prasarana belajar guna menunjang proses yang positif terhadap prestasi belajar siswa. Media pembelajaran merupakan bagian integral dari proses belajar mengajar, oleh sebab itu dalam pemilihan media harus melihat semua komponen dari perencanaan pembelajaran seperti tujuan, materi, pendekatan dan metode, serta bentuk evaluasi termasuk tingkat perkembangan intelektual siswa (Winataputra, 1993).

guru merupakan syarat utama keberhasilan Proses Belajar Mengajar (PBM) di kelas. Keberhasilan seorang guru dalam melaksanakan tugasnya tidak hanya tergantung dari penguasaan cara atau teknik-teknik penyampaian materi pelajaran, tetapi guru harus pandai dalam memilih media pembelajaran yang sesuai dan mampu menggunakan media pembelajaran secara efektif dan efisien (Wahyana dan Winataputra, 2001).

Teknologi Pendidikan merupakan suatu pengembangan, implementasi dan penilaian terhadap sistem-sistem, teknik, dan alat bantu dalam memperbaiki dan meningkatkan proses belajar mengajar manusia. Dalam hal ini yang diutamakan di sini yakni proses belajar dan disamping itu juga terdapat adanya alat-alat yang dapat mebantu proses belajar dan pembelajaran. Sehingga teknologi pendidikan terkait dengan software maupun hardwarenya. Software berupa menganalisis dan mendesain langkah-langkah atau prosedur dalam pembelajaran berdasarkan dari tujuan yang ingin dicapai dengan metode penyajian serta penilaian keberhasilannya. Sedangkan hardwarenya merupakan alat peraga, alat dalam pembelajaran seperti audio, film opaque projector, overhead projector, tv, video tape recorder, komputer, dll Rahayu (dalam Savitri2018:1).

Ada lima kawasan dalam Teknologi Pendidikan yang dikemukakan oleh Seels \& Richey (1994) dalam sebuah sumber yaitu: Pertama, kawasan desain meliputi: desain sistem pembelajaran, desain pesan, strategi pembelajaran, dan karakteristik pembelajar, Kedua, kawasan pengembangan meliputi: teknologi cetak, teknologi audiovisual, teknologi berbasis 
komputer, dan teknologi terpadu. Ketiga, kawasan pemanfaatan meliputi: pemanfaatan media, difusi inovasi, implementasi, dan institusionalisasi serta kebijakan dan regulasi. Keempat, kawasan pengelolaan meliputi: manajemen proyek, manajemen proyek, manajemen proyek, manajemen sumber, manajemen sumber penyampaian, dan manajemen informasi. Kelima, kawasan penilaian meliputi: analisis masalah, pengukuran acuan patokan, evaluasi formatif, dan evaluasi sumatif. Wahyudin (dalam Saputra,2018: 1).

Dari uraian di atas, sesuai dengan kajian penelitian yang akan di laksanakan yaitu tentang media pembelajaran, dimana media pembelajaran termasuk dalam kawasan desain teknologi pendidikan yaitu pemamfaatannya. Media pembelajaran merupakan teknik yang harus dimiliki oleh para pendidik maupun calon pendidik. Hal tersebut sangat dibutuhkan dan sangat menentukan kualifikasi atau layak tidaknya menjadi seorang pendidik. Karena proses pembelajaran itu memerlukan seni, dan ilmu guna menyampaikan materi kepada siswa sesuai dengan tujuan, efisiensi.

Dengan pemberian stimulus yang berupa media pembelajaran, siswa bisa merespon dengan sikap ketertarikan maupun sikap yang biasa saja.Apabila siswa tertarik maka akana lebih semangat lagi dalam belajar melalui media tersebut.Dewasa ini, terdapat berbagai macam media pembelajaran yang di gunakan dalam pendidikan formal maupun non formal (Rusman, 2013:166).Mengelompokan media pembelajaran menjadi empat, yaitu media teknologi cetak, media teknologi audio-visual, media teknologi berbasis komputer, dan media gabungan teknologi cetak dan komputer.Salah satu media berbasis komputer ialah MYOB.MYOB pembelajaran adalah sebuah media sotware akuntansi yang berfungsi membantu pembelajaran dalam bagian keuangan, dalam menyusun laporan keuangan, lengkap dengan penjualan, pembelian aset perusahaan yang di simpan secara otomatis dan tersaji secara detail (Lubis, 2007:3).

Media $M Y O B$ Pembelajaran merupakan media pembelajaran berbasis komputer yang dirancang untuk perusahaan.Program $M Y O B$ jelas sangat bermanfaat bagi siswa, baik SMA atau SMK, yang berkeinginan bekerja sebagai tenaga administerasi di perusahaan (Lubis, 2007:3).Karena media $M Y O B$ pembelajaran di rancang menggunakan aktivitas perusahaan di rasa cocok untuk siswa SMK yang ada mata pelajaran akuntansi.

Pada sekolah menegah kejuruan (SMK) khususnya terdapat mata pelajaran akuntansi, jika hanya menggunakan pembelajaran secara konvensional yang di mana pembelajaran konvensional ini adalah pendidik menjelaskan didepan kelas, dan siswa hanya mendengarkan saja di bangku belajar sendiri. Menurut Sukandi dalam Zakki (2003:8) pembelajaran konvensional ditandai dengan guru mengajar lebih banyak mengajar tentang konsep-konsep bukan kompetensi, tujuannya adalah siswa mengetahui sesuatu bukan mampu mengetahui sesuatu dan pada saat proses pembelajaran siswa. Lebih banyak mendengarkan sehingga siswa merasa bosan dan bingung pada mata pelajaran akuntansi, sehingga nilai yang di hasilkan masih kurang dari keriteria ketuntasan minimal (KKM). Jadi jika mengiginkan hasil yang bagus dalam peroses belajar mengajar (KBM) maka perlu sebuah inovasi baru. Dalam dunia pendidikan tidak cukup dengan pembelajaran konvensional tetapi perlu media yang memudahkan di gunakan dalam proses pembelajaran akuntansi yaitu MYOB, Zahir, Accurate, dan Microsft Excel.Dari berbagai sofwere akuntansi ini mempuyai kelebihan dan kekurangan masing-masing, tapi peneliti lebih tertarik dengan software MYOB. $M Y O B$ ini merupakan kependekan dari Mind Your Own Busainess, yang digunakan sebagai aplikasi pengotomatisasian pembukuan yang mudah digunakan dan mampu menampilkan laporan keuangan secara lengkap, cepat dan akurat. MYOB pembelajaran memiliki yang terdifinisi dengan sangat jelas, terdapat beberapa modul yang di sajikan untuk mengelola data akuntansi sehingga pengguna hanya perlu mengoprasikannya. keunggulan dari media $M Y O B$ pembelajaran ini adalah mudah mengerti dan di pelajari, sangat fleksibel dan langsung dapat dioprasikan, siswa mempunyai daya saing di dalam dan luar negeri saat mencari lapangan pekerjaan, mempunyai pengalaman bekerja dengan data perusahaan dengan menggunakan $M Y O B$ pembelajaran, siswa akan siap pakai dalam dunia usaha, akan mendapatkan praktik lapangan langsung dalam dunia bisnis, siswa akan di perkaya dengan setudi kasus. Tidak hanya itu di bandingkan dengan zahir, accurate, MYOB ini telah lama dikembangkan sehingga $M Y O B$ sudah semestinya tepat di gunakan di SMK yang besiknya kejuruan dan mempunyai mata pelajaran akuntansi. Penelitian yang pernah dilakukan oleh Deskoni, (2017: 44) menyimpulkan bahwa ada Pengaruh Software MYOB Accounting Terhadap Hasil Belajar Akutansi Siswa Di SMA Muhammadiyah 6 Palembang. 
Berdasarkan latar belakang di atas, maka peneliti perlu untuk mengadakan suatu penelitian dengan Judul " Apakah ada effektivitas Penggunaan Media MYOB Pembelajaran Terhadap Hasil Blajar Pada Mata Pelajaran Akuntansi Kelas XI di SMKN 1 Sakra Kecamatan Sakra Kabupaten Lombok Timur Tahun Ajaran 2019/2020”.

\section{TINJAUAN PUSTAKA}

\section{Media Pembelajaran}

a. Pengertian Media Pembelajaran

Kata media berasal dari bahasa latin yang merupakan sebuah bentuk jamak dari medium yang berarti perantara atau pengantar. Menurut Sadiman dkk dalam Prayatna, (2015:8) metode adalah perantara atau pengantar pesan dari pengirim ke penerima pesan.

Penggunaan media pembelajaran dalam peroses pendidikan mempunyai bagian yang vital dalam mewujudkan proses kegiatan pembelajaran yang efektif dan mendapatkan hasil yang baik. Penggunaan media selama pembelajaran dapat mempasilitasi dan meningkatkan kualitas pembelajaran (Arsyad, 2016:4) menggunakan pengertian media pembelajaran dapat di maknai secara luas dan sempit. Secara luas media di artikan setiap orang, Materi atau peristiwa yang memberikan kesempatan pada siswa untuk memperoleh pengetahuan, keterampilan dan sikap.Dalam arti sempit, Media pembelajaran adalah Sarana non personalyang di gunakan oleh guru untuk mendukung peroses belajar mengajar agar mencapai kompetensi.

Berdasarkan pengertian yang telah di bahas di atas, maka dapat di ambil jalan tengah pernyataan bahwa media pembelajaran adalah suatu bentuk sarana yang dapat merangsang pemikiran, perasaan, perhatian, dan minat siswa sehingga terjadi proses belajar dan mencapai kompetensi yang di harapkan.

\section{Media $M Y O B$ Pembelajaran}

a. Pengertian Media

Media MYOB Pembelajaran adalah suatu program aplikasi yang di gunakan untuk mengoptimalisasikan pembukuan secara lengkap, cepat dan akurat. Dengan jumlah fasilitas umum yang lengkap namun tetap memiliki karakteristik yang sama yaitu memasukan daftar akun, pengaturan, pengelolaan Bank, pelanggan pemasok, produk hingga sampai pada laporan keuangan seperti neraca, labarugi, dan sebagainya.

Menurut Lubbis (2007 : 1), $M Y O B$ adalah software akuntansi yang berfungsi membantu bagian keuangan dalam menyusun laporan keuangan, lengkap dengan pengendalian inventory, penjualan, pembelian aset perusahaan, bahkan tersedia lebih dari 150 jenis laporan keuangan yang tersimpan secara otomatis dan tersaji secara detail.

Sedangkan secara umum, pengertian $M Y O B$ Pembelajaran adalah sebuah software akuntansi yang diperuntukkan bagi usaha kecil dan menengah (UKM) yang dibuat secara terpadu (inteegrated software).

a. Kelebihan dan Kekurangan $M Y O B$ Pembelajaran

Terdapat berbagai kelebihan dan kekurangan MYOB menurut Kuntoro dkk, (2008 : 1) bahwa: Kelebihan MYOB Pembelajaran yakni: . a) User friendly (mudah digunakan), bahkan oleh orang awam yang tidak mempunyai pengetahuan mendasar tentang akuntansi. b) Tingkat keamanan yang cukup valid untuk setiap user. c) Kemampuan eksplorasi semua laporan ke program Excel tanpa melalui proses ekspor/impor file yang merepotkan. d) Kemampuan trash back semua laporan ke sumber dokumen dan sumber transaksi. e) Dapat diaplikasikan untuk 105 jenis perusahaan yang telah direkomendasikan. f) Menampilkan laporan keuangan komparasi (perbandingan) serta menampilkan analisis laporan dalam bentuk grafik. Kekurangan MYOB. a) Data base MYOB nerupakan database yang di kunci. b) 
MYOB Pembelajaran merupakan Sofware buatan luar negeri. c) Tidak ada modul fixed assets. d) Tidak dapat di gunakan untuk perusahaan dengan mulai company.

Menurut Supriyatna, (2015 : 11) kelebihan MYOB Pembelajaran adalah :a) Mudah dimengerti dan dipelajari. b) Sangat fleksibel dan langsung dapat dioprasikan. Adapun kekurangan yaitu: a) Tidak ada fitur perpajakan. b) Tidak dapat memodipikasi laporan maupun memodipikasi file. c) diperlukan modul.

Dari pendapat ahli diatas, maka dapat diambil jalan tengah kelebihan $M Y O B$ Pembelajaran adalah penggunaan user friendly atau fleksibel memuat tingkat keamanan yang cukup valid untuk setiap penggunaan dengan kemampuan eksplorasi semua laporan tampa melaui ekspor impor yang sulit. Kekurangan MYOB Pembelajaran adalah: laporan konsolidasi perusahaan multi compny tidak dapat dibuat dan digunakan dengan $M Y O B$, pengelolaan atas barang konsiyasi relatif sulit karna kelemahan multi wareshous.

b. Langkah-langkah Pembelajaran $M Y O B$ dalam KBM

Langkah-langkah pembelajaran $M Y O B$ dalam KBM sebagai berikut: Pada awalnya guru menjelaskan tatacara penggunaan aplikasi $M Y O B$. 2) Jika penjelasan selsai maka giliran siswa itu sendiri yang akan menggunakan aplikasi $M Y O B$ pada Komputer yang telah di sediakan. 3) Jadi dalam proses pembelajaran guru sebagai pasilitator dan mengawasi siswa dalam proses KBM. 4) Setelah siswa memahami, siswa boleh bertanyaapa saja yang belum di mengerti. 5) Begitu siswa sudah bisa menggunakan aplikasi $M Y O B$ Pembelajaran maka siswa akan mengerjakan tugas untuk mengetahui sejauh mana pemahaman mereka.

\section{Hasil Belajar}

a. Pengertian Hasil Belajar

Susanto, (2013:4) Hasil Belajar adalah Perubahan-perubahan pada diri siswa, baik yang menyangkut aspek kongnitif, afektif, dan psikomotor sebagai hasil dari kegiatan belajar.Sedangkan Menurut (Purwanto 2014:42) hasil belajar dapat diartikan kata gori yang kia berikan pada stimulus dilinkungan yang menyediakan sekema yang terorganisasi untuk mengasimilasi stimulus-stimulus baru dan menentukan huungan didalam dan diantara katagori-kaagori.

Dari definisi ahli di atas, maka dapat diambil kesimpulan bahwa hasil belajar adalah prestasi belajar yang dicapai siswa dalam proses kegiatan belajar mengajar dengan membawa suatu perubahan dan pembentukan tingkah laku seseorang.

b. Faktor-faktor yang Mempengaruhi Hasil Belajar

Hasil belajar adalah kemampuan yang dimiliki peserta didik setelah dia menerima pengalamanyang di peroleh mencakupranah kongnitif, afektif dan psikomotorik. Hasil belajar siswa dapat dipengaruhi oleh berbagai hal. Secara umum Hasil belajar dipengaruhi 2 hal, yaitu faktor internal dan faktor eksternal: Faktor internal, yaitu Faktor internal yang mempengaruhi hasil belajar yang pertama adalah Aspek fisiologis. Untuk memperoleh hasil Hasil belajar yang baik, kebugaran tubuh dan kondisi panca indera perlu dijaga dengan cara: makanan/minuman bergizi, istirahat, olah raga. Tentunya banyak kasus anak yang prestasinya turun karena mereka tidak sehat secara fisik. Faktor internal yang lain adalah aspek psikologis. Aspek psikologis ini meliputi: inteligensi, sikap, bakat, minat, motivasi dan kepribadian. Faktor psikologis ini juga merupakan faktor kuat dari hasil belajar, intelegensi memang bisa dikembangkang, tapi sikap, minat, motivasi dan kepribadian sangat dipengaruhi oleh faktor psikologi diri kita sendiri. Oleh karena itu, berjuanglah untuk terus mendapat suplai motivasi dari lingkungan sekitar, kuatkan tekad dan mantapkan sikap demi masa depan yang lebih cerah. 2) Faktor eksternal.yaitu factor yang berasal dari luar diri siswa, yang termasukdalam factor eksternal adalah factor keluarga dan factor sekolah. Faktor keluarga yaitu siswa yang belajar akan menerima pengaruh dari keluarga berupa cara orang tua mendidik, suasana rumah tangga dan keadaan ekonomi keluarga. Sedangkan factor sekolah yang mempengaruhi factor belajar mencakup metode mengajar, kurikulum, relasi guru dengan siswa, disiplin sekolah pelajaran dan waktu sekolah, setandar 
pelajaran, keadaan gedung, metode belajar dan tugas rumah. Slameto (dalam Nila, 2010:54).

\section{METODE PENELITIAN}

\section{A. Rancangan Penelitian}

Rancangan penelitian ini adalah suatu pendekatan yang digunakan dalam suatu penelitian. Dalam buku Metode Penelitian dijelaskan bahwa, "rancangan pada dasarnya merupakan keseluruhan peroses pemikiran dan penetuan matang tentang hal-hal yang dilakukan. Rancangan merupakan landasan berpijak, serta dapat juga dijadikan dasar penelitian, baik oleh peneliti itu sendiri maupun orang lain terhadap peneliti dan bertujuan memberikan jawaban terhadap langkah-langkah yang diambil" (Margono, 2004:100).

Adapun rancangan penelitian yang digunakan yaitu metode penelitian kuantitatif deskriptif dengan pendekatan eksperimen. Desain penelitian yang digunakan dalam penelitian ini adalah pola one-group pretest-posttest design, yang digambarkan sebagai berikut:

\footnotetext{
$\mathrm{O}_{1} \times \mathrm{O}_{2}$

Gambar 1.1 : Rancangan Penelitian

Keterangan:

$\mathrm{O}_{1}=$ Nilai Pre-test

$\mathrm{X}=$ Treatmen $/$ Perlakuan

$\mathrm{O}_{2}=$ Nilai Poset-test (Sugiyono, 2014: 110).
}

\section{B. Populasi dan Sampel}

1. Populasi

Populasi adalah seluruh data yang menjadi perhatian kita dalam dalam suatu ruang lingkup dan waktu yang kita tentukan (Margono, 2004:118). Dalam penelitian ini yang menjadi populasi adalah seluruh siswa kelas XI Akomodasi pertanian 25 orang.

2. Sampel

Dalam menentukan sampel, penelitian ilmiah memiliki peran penting, karena jika teknik pengambilan sampelnya salah maka data yang akan diperoleh salah. Sedangkan penentuan jumlah sampel tergantung pada besarnya jumlah populasi, "Jika populasi kurang dari 100, dianjurkan agar semuanya dijadikan sampel. Namun jika populasi lebih dari 100, maka dapat diambil 10-15\%, 20-25\% atau lebih tergantung kemampuan peneliti” (Suharsimi, 2006: 134). Menurut Sugiyono (2010: 81) “ sampel adalah bagian dari jumlah dan karakteristik yang di miliki oleh populasi tersebut”.

Dari pendapat di atas, dapat disimpulkan bahwa sampel adalah sebagian dari wakil populasi yang akan diteliti. Adapun dalam penelitian ini menggunakan teknik study populasi yaitu seluruh siswa kelas XI Akomodasi Pertanian SMKN 1 Sakra Kabupaten Lombok Timur Tahun Ajaran 2018/2019 yang berjumlah 25 orang.

\section{Teknik Pengumpulan Data}

Dalam penelitian ini terdiri dari variabel yaitu pengaruh media $M Y O B$ Pembelajaran terhadap hasil belajar siswa. Untuk mendapatkan data-data tersebut, maka metode pengumpulan data yang digunakan adalah metode tes sebagai metode pokok sedangkan metode dokumentasi sebagai metode pelengkap. Masing-masing metode tersebut dapat dijelaskan sebagai berikut:

a. Metode tes

Tes merupakan instrument alat ukur pengumpulan data dimana dalam memberikan respon atas pertanyaan dalam instrumen. Peserta di dorong untuk menunjukan penampilan maksimalnya. Menurut Purwanto (dalam Wijaya 2017:36). 
Tes sebagai instrumen pengumpul data adalah serangkaian pertanyaan atau latihan yang digunakan untuk mengukur keterampilan pengetahuan, intelegensi, kemampuan atau bakat yang dimiliki oleh individu atau kelompok. Ridwan (Wijaya, 2017:36). Sedangkan menurut pendapat ahli lain adalah metode tes merupakan kemampuan dasar untuk mengukur kemampuan dan pencapaian atau prestasi. Suharsimi (Wijaya 2017:36).

Jadi metode tes dilakukan untuk mengetahui sejauh mana hasil belajar siwa dalam materi akuntasi yaitu memperoses transaksi keuangan, materi ini menuntut siswa untuk lebih aktifdan fokus dalam memperhatikan tata cara pada saat mengoprasikan $M Y O B$ Pembelajaran dalam peroses pembelajaran.

Adapun tes yang digunakan sebagai instrument pengumpulan data yaitu pre-test dan pos-test. Pre-test yaitu suatu bentuk pertanyaan yang di lontarkan oleh guru kepada muridnya sebelum memulai suatu pelajaran. Sedangkan pos-test merupakan bentuk pertanyaan yang diberikan setelah pelajaran/materi disampaikan atau untuk mengetahui hasil belajar siswa setelah menerapakan media MYOB Pembelajaran dengan bentuk soal yang sama yaitu 25 butir soal pilihan ganda yang sudah diuji validitas dan relibitas. jadi instrument penelitian ini sudah diuji validitas relibilitas datanya dari kelas lain yaitu XI jurusan akomodasi pertanian.

b. Dokumentasi

Dokumentasi adalah pengumpulan data dengan cara mengambil data-data dari catatan-catatan, dokumentasi, administrasi yang sesuai dengan masalah yang di teliti. Dalam hal ini dokumentasi di peroleh melalui dokumen-dokumen atau arsip-arsip.

\section{Teknik Analisis Data}

Dalam penelitian kuantitatif, teknik analisis data diarahkan untuk menjawab rumusan masalah atau menguji hipotesis yang dirumuskan. Karena datanya kuantitatif, maka teknik analisis data menggunakan metode statistik yang telah tersedia. Analisis data adalah peroses mencari dan menyusun secara sistematis data yang diperoleh dari hasil wawancara, dokumentasi, dan catatan lapangan dengan cara mengorganisasikan data ke dalam katagori, menjabarkan ke dalam unit-unit, melakukan sintesa menyusun kelompok, memilih mana yang penting dan yang akan dipelajari, dan membuat kesimpulan sehingga mudah dipahami oleh diri sendiri maupun orang lain. Sugiono (Wijaya, 2017:38).

Sehubung dengan penelitian ini maka sesuai dengan gejala yang diteliti yaitu pengaruh media $M Y O B$ Pembelajaran terhadap hasil belajar siswa maka rumusan yang digunakan adalah rumusan t-tes sebagai berikut:

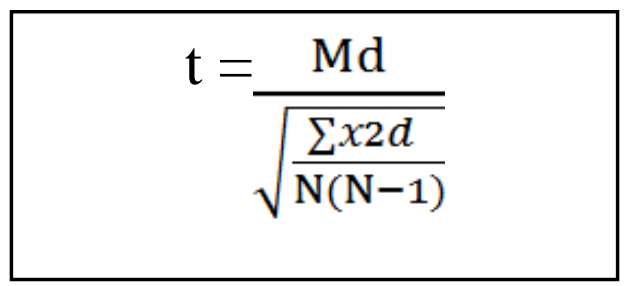

Gambar 1.2 Rumus T-test

Keterangan :

$\mathrm{Md}=$ Mean dari perbedaan pre tes dengan postes (post test-pre test)

$\mathrm{xd} \quad=$ Deviasi masing-masing subjek $(\mathrm{d}-\mathrm{Md})$

$\sum x d^{2} \quad=$ Jumlah kuadrat deviasi

$\mathrm{N} \quad=$ Subjek pada sampel

d.b $\quad=$ Ditentukan dengan N-1

(Suharsimi,2010:349) berikut:

Adapun langkah-langkah analisis data penelitian yang dilakukan adalah sebagai

c. Merumuskan hipotesis nihil $\left(\mathrm{H}_{0}\right)$

d. Membuat tabel kerja 
e. Memasukan data dalam rumus

f. Menguji signifikan Nilai t-tes

g. Menarik kesimpulan

\section{HASIL PENELITIAN DAN PEMBAHASAN}

\section{A. Hasil Penelitian}

Untuk mendapatkan data yang dibutuhkan dalam penelitian yakni data tentang Efektivitas Penggunaan Media $M Y O B$ Pembelajaran Terhadap Hasil Belajar Siswa Pada Mata Pelajaran Akuntansi Kelas XI di SMKN 1 Sakra Tahun Pelajaran 2019/2020, maka yang ditempuh dalam penelitian ini adalah sebagai berikut: 1) Persiapan Penelitian, 2) Pelaksanaan Penelitian, 3) Data yang Diperoleh, 4) Analisis Data.

\section{B. PengujianHipotesis}

Adapun langkah-langkah yang ditempuh dalam pengujian hipotesis yaitu sebagai berikut:

1. Merumuskan Hipotesis Nihil $\left(\mathrm{H}_{0}\right)$

Dalam bab II dia jukan hipotesis alternatif (Ha) yang berbunyi ada efektivitas penggunaan media MYOB Pembelajaran terhadap hasil belajar siswa pada mata pelajaran akuntansi kelas XI di SMKN 1 Sakra Tahun Pelajaran 2019/2020. Sehingga perlu diubah terlebih dahulu kedalam hipotesis nihil $\left(\mathrm{H}_{0}\right)$ sehingga berbunyi tidak ada efektivitas penggunaan media MYOB Pembelajaran terhadap hasil belajar siswa pada mata pelajaran akuntansi kelas XI di SMKN 1 Sakra Kabupaten Lombok Timur Tahun Ajaran 2019/2020.

2. Menyusun Tabel Kerja

Sesuai dengan rumus yang digunakan, maka table kerja yang dibutuhkan adalah table kerjau ntuk menguji hipotesis yang akan disajikan padat abel berikut ini:

Tabel 03.Tabel Kerja Untuk Pengujian HipotesisTentang Efektivitas

Penggunaan Media MYOB Pembelajaran Terhadap Hasil Belajar Siswa

Pada Mata Pelajaran Akuntansi Kelas XI di SMKN 1 Sakra Tahun Ajaran 2019/2020.

\begin{tabular}{|c|c|c|c|c|c|c|}
\hline \multirow[t]{2}{*}{ No } & \multirow{2}{*}{$\begin{array}{l}\text { Kod } \\
\text { e } \\
\text { Sub } \\
\text { yek }\end{array}$} & $\begin{array}{l}\text { Pr } \\
\text { e- } \\
\text { tes } \\
\text { t }\end{array}$ & $\begin{array}{l}\text { Po } \\
\text { st- } \\
\text { tes } \\
\text { t }\end{array}$ & $\begin{array}{l}\text { Gain } \\
\text { (d) }\end{array}$ & $\begin{array}{l}\text { Xd } \\
\text { B }\end{array}$ & \multirow[t]{2}{*}{$\mathbf{b}^{2}$} \\
\hline & & $\begin{array}{l}\mathrm{CO}_{1} \\
)^{-1}\end{array}$ & $\begin{array}{l}\mathrm{CO}_{2} \\
)\end{array}$ & $\begin{array}{l}\left(\mathrm{O}_{2^{-}}\right. \\
\left.\mathrm{O}_{1}\right)\end{array}$ & $\begin{array}{l}\text { (d- } \\
\text { Md } \\
\text { ) }\end{array}$ & \\
\hline 1 & $\mathrm{AH}$ & 44 & 52 & 8 & -14 & 196 \\
\hline 2 & $\mathrm{AA}$ & 48 & 72 & 24 & 2 & 4 \\
\hline 3 & LH & 44 & 64 & 20 & -2 & 4 \\
\hline 4 & DRO & 36 & 48 & 12 & -10 & 100 \\
\hline 5 & IT & 36 & 60 & 24 & 2 & 4 \\
\hline 6 & $\mathrm{KS}$ & 28 & 60 & 32 & 10 & 100 \\
\hline 7 & KP & 44 & 64 & 20 & -2 & 4 \\
\hline 8 & $\mathrm{RS}$ & 44 & 72 & 28 & 6 & 36 \\
\hline 9 & SR & 48 & 76 & 28 & 6 & 36 \\
\hline 10 & $\mathrm{SH}$ & 44 & 68 & 24 & 2 & 4 \\
\hline 11 & SM & 48 & 68 & 20 & -2 & 4 \\
\hline 12 & WW & 36 & 52 & 16 & -6 & 36 \\
\hline 13 & YA & 40 & 60 & 20 & -2 & 4 \\
\hline 14 & TA & 36 & 60 & 24 & 2 & 4 \\
\hline 15 & JRA & 40 & 64 & 24 & 2 & 4 \\
\hline 16 & JA & 36 & 64 & 28 & 6 & 36 \\
\hline 17 & RRA & 48 & 72 & 24 & 2 & 4 \\
\hline 18 & $\mathrm{AO}$ & 44 & 72 & 28 & 6 & 36 \\
\hline 19 & MS & 36 & 68 & 32 & 10 & 100 \\
\hline 20 & MA & 36 & 60 & 24 & 2 & 4 \\
\hline
\end{tabular}




\begin{tabular}{|l|l|l|l|l|l|l|}
\hline 21 & SN & 44 & 64 & 20 & -2 & 4 \\
\hline 22 & S & 48 & 60 & 12 & -10 & 100 \\
\hline 23 & AP & 48 & 56 & 8 & -14 & 196 \\
\hline 24 & KK & 36 & 60 & 24 & 2 & 4 \\
\hline 25 & KA & 40 & 64 & 24 & 2 & 4 \\
\hline \multirow{4}{*}{$\mathbf{N}=\mathbf{2 5}$} & $\begin{array}{l}\mathbf{1 0 3} \\
\mathbf{2}\end{array}$ & $\begin{array}{l}\mathbf{1 5 8} \\
\mathbf{0}\end{array}$ & 548 & & \\
\cline { 2 - 5 } & $\begin{array}{c}\mathbf{4 1} \\
\mathbf{2 8}\end{array}$ & $\begin{array}{l}\mathbf{6 3 ,} \\
\mathbf{2}\end{array}$ & $\begin{array}{l}\mathbf{2 1 , 9 2} \\
\end{array}$ & $\mathbf{2 0 2}$ & & \\
\hline
\end{tabular}

Setelah mengetahui deviasi dari masing-masing data kelas eksperimen dan kelas ko maka langkah selanjutnya adalah memasukan data ke dalam rumus. Untuk lebih jelas . dilihat sebagai berikut:

3. Memasukan Data ke dalam Rumus

Data yang terdapat di dalam tabel di atas, dianalisis dengan menggunakan rumus $T$-test sebagai berikut:

$$
\begin{aligned}
& \mathrm{MB}=\frac{\sum \mathrm{B}}{N}=\frac{548}{25}=21,92 \\
& t=\frac{21,92}{\sqrt{\frac{1028}{25(25-1)}}} \\
& t=\frac{21,92}{\sqrt{\frac{1028}{25(24)}}} \\
& t=\frac{21,92}{\sqrt{\frac{1028}{600}}} \\
& t=\frac{21,92}{\sqrt{1,713}} \\
& t=12.796
\end{aligned}
$$

4. Menguji Nilai T-test

Sesuai dengan hasil perhitungan t-test yang diperoleh melalui analisis ternyata nilai yang diperoleh $=12.796$, sedangkan nilai $t$-test dalam tabel dengan $\mathrm{db}(\mathrm{N}-1)=25-1=24$ dengan taraf signifikansi $5 \%=2,064$, dengan demikian bahwa nilai $t$-test analisis lebih besar dari pada nilai t tabel $(12.796>2,064)$. Hal ini berarti hipotesis nol ditolak dan hipotsis alternatif diterima.

5. Kesimpulan

Dari hasil uji $t$-test menunjukkan nilai $t$ hitung sebesar 12.796 maka berdasarkan taraf signifikansi $5 \%$ dan d.b $=24$ ternyata besarnya angka batas penolakan hipotesis nol yang dinyatakan dalam tabel distribusi $t$ adalah 2,064.

Kenyataan ini menunjukkan bahwa nilai $t$ hitung lebih besar dari pada nilai $t$ tabel (12.796> 2,064). Karena $t$ hitung lebih besar dari nilai $t$ tabel, maka penelitian ini dikatakan signifikan. Hal ini berarti bahwa hipotesis nol ditolak dan hipotesis alternatif diterima, maka dapat ditarik kesimpulan bahwa: Ada Efektivitas Penggunaan Media MYOB Pembelajaran Terhadap Hasil Belajar Siswa Pada Mata Pelajaran Akuntansi Kelas XI di SMKN 1 Sakra Kabupaten Lombok Timur Tahun Ajaran 2019/2020.

\section{Pembahasan}

Dari analisis data dilakukan dua kali yaitu sebelum dan setelah menggunakan Media $M Y O B$ Pembelajaran. Karena dalam penelitian ini menggunakan one group pre test - post test design, maka dari hasil uji t-test menunjukkan nilait hitung sebesar 12.796 maka berdasarkan taraf signifikan 5\% dan d.b $=24$ ternyata besarnya angka batas penolakan hipotesis nihil (Ho) yang dinyatakan dalam tabel distribusi $t$ adalah 2,064 Kenyataan ini menunjukkan bahwa nilai $t$ hitung lebih besar dari pada nilait tabel $(12,796>2.064)$, karena $t$ 
hitung lebih besar dari angka $t$ tabel, maka penelitian ini signifikan yakni Ada Efektivitas Penggunaan Media $M Y O B$ Pembelajaran Terhadap Hasil Belajar Siswa Pada Mata Pelajaran Akuntansi Kelas XI di SMKN 1 Sakra Kabupaten Lombok Timur Tahun Ajaran 2019/2020. Dengan demikian, bahwa nilai rata-rata siswa meningkat setelah menggunakan media $M Y O B$ pembelajaran dibandingkan dengan sebelum menggunakan Media $M Y O B$ Pembelajaran dalam pembelajaran atau dengan menggunakan pembelajaran secara konvensional.

Berdasarkan hasil penelitian, pre-test digunakan untuk mengetahui kemampuan awal siswa, kemudian diterapkan suatu aplikasi pembelajaran dari berbagai sumber, setelah itu siswa diberikan post-test untuk mengetahui kemampuan siswa setelah menggunakan media $M Y O B$ Pembelajaran. Sehingga dapat dilihat perubahan saat guru belum menggunakan media $M Y O B$ Pembelajaran dengan setelah guru menggunakan media $M Y O B$ Pembelajaran.

Pada penelitian ini jenis penelitian yang digunakan yaitu kuantitatif dan model penelitiannya yaitu eksperimen, sedangkan strategi penelitian yang digunakan adalah one-group pretes-posttest design. Dalam buku metode penelitian dijelaskan bahwa, "rancangan pada dasarnya merupakan keseluruhan proses pemikiran dan penentuan matang tentang hal-hal yang dilakukan. Rancangan landasan berpijak, serta dapat pula dijadikan dasar penelitian, baik oleh peneliti itu sendiri maupun orang lain terhadap penelitian dan bertujuan memberikan jawaban terhadap langkah-langkah yang diambil" (Margono, 2012: 100). Sedangkan ahli lain berpendapat bahwa rancangan pada dasarnya merupakan keseluruhan proses penelitian dan penentuan yang berlangsung tentang hal-hal yang dilakukan.

Rancangan penelitian ini adalah pedoman yang berisi langkah-langkah yang akan diikuti oleh peneliti untuk melakukan penelitiannya (Sugiono, 2014:302).

Jenis tes yang digunakan dalam penelitian ini berbentuk multiple choice test (pilihan ganda) terdiri atas suatu keterangan atau pemberitahuan tentang suatu pengertian yang belum lengkap. Dan untuk melengkapinya harus memiliki satu dari beberapa kemungkinan jawaban yang telah disediakan. Multiple choice test terdiri atas bagian keterangan dan bagian kemungkinan jawaban atau alternatif. Kemungkinan jawaban terdiri dari satu jawaban benar dan beberapa jawaban yang salah sebagai pengecoh.

\section{KESIMPULAN}

\section{A. Simpulan}

Berdasarkan hasil analisis data menggunakan uji $t$ setelah data dianalisis menggunakan uji-t dan diperoleh nilai $t$ hitung sebesar 12.796 dan nilai $t$-tabel pada taraf signifikan 5\% diperoleh nilai $t$ tabel sebesar 2.064. karena $t$ hitung diperoleh lebih besar dari $t$ tabel yakni $(12.796>2$,064) maka penelitian ini dinyatakan signifikan. Dengan demikian dapat disimpulkan bahwa "Ada Efektivitas Penggunaan media $M Y O B$ Pembelajaran Terhadap Hasil Belajar Siswa Pada mata pelajaran Akuntansi Kelas XI di SMKN 1 Sakra Kabupaten Lombok Timur Tahun Pelajaran 2019/2020".

B. Saran

Dari kesimpulan yang diperoleh dalam penelitian ini, maka dapat diajukan beberapa yaitu kepada:

1. Kepala Sekolah, agar dapat menyediakan fasilitas berupa sarana dan prasarana untuk guru.

2. Guru, agar dapat menggunakan serta menerapkan Media MYOB dalam proses pembelajaran.

3. Siswa, supayadapat menumbuhkan motivasi dan minat belajar siswa sehingga dapat meningkatkanHasil belajar.

4. Peneliti lain, supaya dapat dijadikan sebagai sumber referensi atau menambah wawasan dalam penelitian - penelitian selanjutnya. 


\section{DAFTAR PUSTAKA}

Arikunto, Suharsimi. 2006. Prosedur Penelitian suatu pendekatan praktik. Jakarta: Rineka Cipta.

Arikunto, Suharsimi. 2010. Prosedur Penelitian suatu pendekatan praktik. Jakarta: Rineka Cipta

Deskoni, dkk. 2017. Pengaruh Software MYOB Acoounting Terhadap Hasil Belajar Akuntansi Siswa di SMA Muhammmadiyah. Palembang:Universitas Sriwijaya

Egidia, Nila 2018. Perbandingan Model Pembelajaran Countextual Teaching Learning dan model sains Teknologi Masyarakat terhadap Hasil Belajar Siswa Pada Matar Pelajaran Biologi Kls x di SMA Islam Yabadi Bebuak Kabupaten Lombok Tengah Tahun Pelajaran 20017/2018. Skripsi: IKIP Mataram

IKIP Mataram, 2011, Pedoman Pembimbing dan Penuliasan Karya Ilmiah Mataram

Khaeruman, dkk.2016. Trik-Trik Mengajar"Lembaga Penelitian dan Pendidikan(LPP) Mandala. IKIP Mataram

Lubis, Irsan. 2009. Buku Komputer Akuntansi MYOB Versi 18 Cetakan Pertama Tanggerag: Penerbit STAP 1 INDONESIA

Margono, S.2004. Metode Penelitian Pendidikan. Rineka Cipta

Mema, Nita. 2011. Kemandirian dan Hasil Belajar Siswa pada Mata Pelajaran Komputer Akutansi dengan Menggunakan Media Tutorial Myob Berbasis ADOBE Captivate. Trenggalek: PT Karya Agung Megah Jaya.

Nurita Putrianti. 2014 Upaya Meningkatkan Kembali Hasil Belajar Siswa. http://wordpres.com/jurnal2014/02/upaya-meningkatkan hasil-belajar-siswa

Prayatna, Arman. 2015. Pengaruh Media Makromedia Flash Pada Pembelajaran Bilangan Bulat Terhadap Aktivitas dan Hasil Belajar siswa MTs. Darul Ansor Pengadang Tahun Pelajaran 2014.Skripsi: IKIP Mataram

Rusman. 2014. Belajar dan Pembelajaran Berbasis Komputer. Alfabeta

Rusman. 2017. Belajar dan Pembelajaran Berbasis Komputer. Alfabeta

Sudjana, Nana dkk.2011. Media Pengajaran Penggunaan dan Pembuatannya .Bandung:Sinar Baru Algensindo.

Sudjana, N, dan Ibrahim. 2010. Penilaian Hasil Proses Belajar Mengajar. Bnadung: PT Remaja Rosdakarya

Sudjana, N. dan Ibrahim.2012. Penelitian dan Penilaian Pendidikan. Bnadung: Sinar Baru Algensindo.

Wijaya, Rodi. 2018. Pengaruh Penggunaan Aplikasi Dreamweaver Terhadap Hasil Belajar Siswa Pada Jurusan Multimedia Kelas X SMKN 1 batukliang utara Kabupaten Lombok Tengah Tahun Pelajaran 2017/2018. Skripsi: IKIP Mataram

Yaumi, Muhammad. 2013. Prinsip-Prinsip Desain Pelajaran. Jakarta: Kencana.

Wahyana dan Winataputra. 2001. Perencanaan dan Pengelolaan Pembelajaran IPA. Jakarta: Pusat Penerbit Universitas Terbuka.

Winataputra. 1993. Strategi Belajar Mengajar. Jakarta : Dirjen Dikti. 